\title{
PENGUATAN PENDIDIKAN KEWARGANEGARAAN MELALUI PENDIDIKAN PESANTREN DALAM MEMBENTUK KEADABAN MORAL SANTRI
}

\author{
Hendri \\ Universitas Al Azhar Indonesia, Jakarta, Indonesia \\ hndr270388@gmail.com
}

\begin{abstract}
As we know that many theories that explain citizenship education are seen from a wide range of perspectives, both about culture, economy, social, political, and religious stemming from the civility of the nation's cultural values. While pesantren is present as an educational institution that has a mission vision of moral presence (morality). These two entities have the same direction in shaping the personality of the nation. The purpose of this study is to examine and analyze in-depth the optimization of pesantren in shaping the moral imperatives involved in citizenship education. Research methods using qualitative. The data collection technique was carried out by observation, documentation, and interview studies. The results obtained in this research are very constructive, namely Islamic boarding schools strengthening through formal, informal and non-formal education so that students in carrying out their daily life always apply morals that reflect the values of Pancasila and Islamic values as a nation with a fresh and religious community.
\end{abstract}

Keywords: citizenship education, education pesantren, santri

\begin{abstract}
Abstrak
Seperti yang kita ketahui bahwa banyak teori-teori yang menjelaskan mengenai Pendidikan Kewarganegaraan dipandang dari berbagai macam perspektif, baik berkenaan dengan budaya, ekonomi, sosial, politik, dan religius yang bersumber dari keadaban nilai-nilai budaya bangsa. Sedangkan pesantren hadir sebagai lembaga pendidikan yang mempunyai visi misi tentang keadaban moral (akhlak). Dua entitas ini punya arah yang sama dalam membentuk keperibadian bangsa. Tujuan penelitian ini untuk mengkaji dan menganalisis secara mendalam mengenai optimalisasi pesantren dalam membentuk keadaban moral yang terintgrasi dalam pendidikan kewarganegaraan. Metode penelitian menggunakan kualitatif. Teknik pengumpulan data dilakukan dengan studi observasi, dokumentasi, dan wawancara. Hasil yang diperoleh dalam penelitian sangat kontruktif, yaitu pesantren melakukan penguatan melalui pendidikan formal, Informal dan nonformal, hingga santri dalam menjalankan kehidupan sehari-hari senantiasa menerapkan moral yang mencerminkan nilai Pancasila dan nilai Islam sebagai bangsa bernegaran dan ummat beragama.
\end{abstract}

Kata kunci: pendidikan kewarganegaraan, pendidikan pesantren, santri 


\section{PENDAHULUAN}

\section{...Tholabul Ilmi Faridhatun Ala Kulli Muslimin Wal Muslimat ...}

Mungkin ungkapan ini yang peneliti rasa tepat untuk menjadi awal lembaran pembuka dari pragraf pertama pendahuluan, sebagai stimulus bagi seluruh manusia khususnya islam bahwa suatu kewajiban bagi seluruh ummat islam untuk menuntut, belajar dan mencari ilmu. Begitu penting peranan pendidikan dalam menciptakan kedaulatan hidup manusia dalam berevolusi dari masa ke masa.

Kita tidak dapat mengingkari berbagai macam kejadian-kejadian anih yang menimpa pada bangsa Indonesia akhir-akhir ini, kejahatan atau perilaku asusila yang dilakukan oleh mereka seakan tak ada habis-habisnya, bahkan kejahatan yang dilakukannya tidak logis untuk mereka lakukan sebagai kodrat manusia yang dikaruniai akal, berbeda dengan hewan. Seperti anak menghamili orang tua, orang tua menghamili anaknya. Orang tua membunuh anaknya, anaknya membunuh orang tuanya. Itu yang terjadi di lingkungan keluarga akhir-akhir ini. Di lingkungan masyarakat lebih dari itu. Masyarakat sudah tidak mengenal lagi tetangga kanan dan kiri, individualisme dijadikan kiblat untuk menjaga harga diri. Idealisme dijadikan taming dalam mempertahankan kehormatan yang justru menghilangkan rasa sosialisme kemanusiaan. Egoisme dijadikan fashion dalam berpenampilan setiap harinya, tanpa melihat kanan kiri yang tidak mampu memakai baju dan harus dihormati.

Di tingkat pemerintah banyak yang tidak mengenal jatidirinya sendiri, sebagai manusia (pejabat) yang memerlukan dan diperlukan oleh orang lain. Monososialis, katanya. Manusia sebagai makhluk individu yang tidak lepas dari lingkungan atau orang lain. Seharusnya berjalan 50\%-50\%. Namun jika lebih tinggi jiwa sosialisnya itu bahkan lebih baik, dibandingkan sebaliknya. Faktanya berbeda, di negara yang terkenal ramah, akur, dan berkekarabatan ini sekarang menjadi negara angkuh, sombong, seperti negara yang tak bertuhan padahal jelas dalam sila pertama disebutkan "Ketuhanan yang Maha Esa" nilai-nilai ketuhanan seharusnya dapat dihayati dengan benar, bahwa manusia itu hanya sebuah alat, tidak ada yang lebih baik kecuali memahami siapa?, dan untuk apa diciptakan?.

Sifat hegomoni membuat para pejabat buta dan tidak mengenal siapa dia, dan untuk siapa ia berada?. Sehingga kecintaan tersebut membuat mereka gelap mata dan lupa daratan. Korupsi dimana-mana, dan tidak pernah terselesaikan dari masa kemasa. Ketimpangan seakan sudah menjadi milik rakyat kecil yang tak berdaya, walau dari priode-kepriode telah banyak menyimpan janji-janji, harapan palsu yang tak pernah terealisasi. Maka apa yang harus dipertanyakan dari mereka?. Sikap mereka, tindakan mereka. Sifat-sifat tersebut lebih parah dari pada hewan. Padahal menurut (MagnisSuseno, 1987) manusia memiliki keunggulan yang tidak dapat dimiliki oleh hewan yaitu walau ia mempunyai ketergantungan pada berbagai kondisi alamiah, namun ia (manusia) masih dapat memilih dan tidak mengikuti. Lain dengan hewan. Jadi manusia itu mempunyai konsistensi sebagai manusia yang diunggulkan dari makhluk lainnya. Mungkin yang dimaksud adalah akal. Akal yang dimiliki oleh manusia tidak dapat dibandingkan dengan makhluk lainnya.

Manusia lebih unggul dari pada Jin, Malaikat dan lainnya karena manusia di karunia akal yang jika di fungsikan dengan baik, maka ia dapat mengalahkan semuanya, baik 
pengetahuannya (Jin), ketaatnya (Malaikat). Begitu juga sebaliknya, jika akal tidak difungsikan dengan baik maka manusia tidak lah hanya sebatas seonggok tubuh yang tidak ada artinya.

Yang harus dipertanyakan kenapa manusia bersifat seperti hewan bahkan kadangkadang melebihi hewan?. Maka jawabannya, karena mereka tidak menggunakan dan memfungsikan akalnya dengan baik. Namun, dalam catatan, akal yang baik hanya dapat difungsikan dengan baik jika mereka mau mendidik akalnya pada didikan yang sehat dan mau melatihnya untuk berpikir positif. Maka kenapa dalam islam pendidikan itu diwajibkan bagi seluruh ummat islam, tentu tujuannya agar akal manusia dapat terdidik dan terarah dalam berpikir.

Mengutip dari nasehat sang tokoh Pendidikan Nasional Indonesia yaitu Ki Hajar Dewantara. Beliau berkata bahwa pendidikan merupakan daya upaya untuk kemajuan pertumbuhan budi pekerti (kekuatan batin, karakter), pikiran (intellect) dan tumbuhnya anak (Budimansyah, 2010, hal. 51). Jadi pendidikan adalah faktor utama dalam menciptakan keadaban dan kebajikan (civic virture) bagi bangsa. Keadaban dalam bersikap, keadaban dalam keluarga, forum, lingkungan, pemerintah, keadaban dalam berkomunikasi, keadaban dalam berinteraksi, keadaban dalam mengambil keputusan/ kebijakan, keadaban dalam memimpin, bahkan sampai yang dipimpin harus mempunyai nilai keadaban. Sehingga semua saling bersinergi, saling menjaga, saling mengontrol, saling mengingatkan dan saling mengamankan dari hal yang negatif.

Bentuk pelanggaran yang terjadi saat ini mulai dari lingkungan keluarga, masyarakat bahkan pemerintah dapat dikatakan karena krisisnya keadaban yang disebabkan kurangnya kesadaran pendidikan yang dimiliki oleh mereka. Maka dari itu peranan pendidikan membawa dampak yang kuat untuk merubah dan meminimalisir tingkat pelanggaran di Indonesia bahkan seluruh dunia. Semua pelajaran harus memberi dampak pada perubahan sikap manusia, khususnya pelajaran Pendidikan Pancasila dan Kewaganegaraan atau Pendidikan Kewarganegaraan (PKn). Menurut Wahab \& Sapriya (2011, hal. 33) Pendidikan Kewarganegaraan adalah pendidikan yang menekankan warga negaranya untuk menjadi warga negara yang baik. Sedangkan warga negara yang baik adalah warga negara yang memahami dan melaksanakan hak-hak dan kewajiban, bertanggung jawab, menghargai hak-hak orang lain, taat hukum serta bayar pajak. Tidak sampai disitu, untuk menjadi warga negara yang baik juga harus bisa mempertahankan serta berperan aktif dalam menjaga kestabilitasan negara, salah satunya dengan menjaga keutuhan bangsa dengan menanamkan nilai-nilai Pancasila pada kehidupan berbangsa dan bernegara.

Pendidikan Kewarganegaraan adalah pendidikan yang membentuk sikap kedewasaan manusia dalam melakukan segala tindakan, keputusan, serta kritis dalam segala hal. Pendidikan Kewarganegaraan juga dapat diartikan sebagai pendidikan karakter, etika, moral yang di dalamnya terdapat nilai-nilai kesopanan, kemandirian, sabar, keikhlasan, keharmonisan, gotong royong, saling membantu, menghormati dan religius. Malik Fajar (dalam Susilo, 2015, hal. 28) mengatakan bahwa Pendidikan Kewarganegaraan sebagai wahana untuk mengembangkan kemampuan, watak dan karakter warga negara demokratis yang bertanggungjawab. Jadi Pendidikan Kewarganegaraan adalah model pendidikan yang mengembangkan potensi warga negara agar menjadi lebih ideal, objektif pada pengembangan moral keadaban dimana saja, salah satunya di lembaga pendidikan di Pondok Pesantren. 
Hal tersebut sesuai dengan pendapat Baso (2012) bahwa akar Pendidikan Kewarganegaraan itu derdapat di Pesantren. Pesantren di nilai sebagai lembaga satusatunya yang masih ideal dalam memberdayakan kultur budaya, mulai dari pembudayaan hasanah karakter, maupun estetika nenek moyang yang sampai saat ini masih terawat di pesantren. Maka dari itu tidak salah jika Ki Hajar Dewantara dan Soetomo (dalam Baso, 2012) mengatakan bahwa pesantren adalah lembaga pendidikan yang ideal untuk diterapkan dan dijadikan rujukan oleh pendidikan-pendidikan lain khususnya di Indonesia.

Namun yang harus diperhatikan dalam perkembangan pendidikan pesantren adalah sebagaimana yang dikemukakan oleh Budiman \& Ismatullah (2015, hal. 158) bahwa keberhasilan pesantren dalam mendidik santrinya tersebut bukan suatu kebetulan, tetapi ada nilai-nilai yang mendasarinya. Owens dalam (Budiman \& Ismatullah, 2015) menyodorkan dimensi soft yang berpengaruh terhadap kinerja individu dan organisasi, yaitu nilai-nilai (values), keyakinan (biliefs), budaya (culture), dan norma perilaku. Jadi, pesantren adalah lembaga pendidikan yang mengembangkan nilai, bersumber dari agama Islam dan juga nilai-nilai Pancasila yang menjadi sumber kehidupan warga negara dalam setiap bertindak, melakukan kebijakan dan menentukan keputusan setiap harinya. Apalagi saat ini pendidikan pesantren dirasa sangat pantas untuk menjadi role model belajar nasional.

Sedangkan yang dimaksud dengan Pendidikan Pesantren dalam membentuk keadaban moral adalah upaya pesantren dalam melakukan penegakan kebajikan dengan cara yang beda dan tidak dimiliki oleh selain pendidkan pesantren itu sendiri. Dengan ini peneliti ingin menciptakan dua demensi ilmu yang saling bersinergi dalam membentuk generasi kewargaan yang baik, berakhlak mulia, ikhlas, jujur, taat, disimplin, dewasa dan religius dalam menjalankan ibadah dan kewajiban sebagai warga negara.

Dari latar belakang diatas yang telah diuraikan secara detail, meliputi data dan faktanya, maka peneliti merumuskan sebuah masalah untuk dicari jawabannya yaitu: bagaimana penerapan pesantren dalam membentuk keadaban moral santri sebagai bentuk penguatan pendidikan kewarganegaraan?.

\section{METODE PENELITIAN}

Pendekatan yang digunakan dalam penelitian ini adalah pendekatan kualitatif, karena dalam penelitian ini, peneliti akan meneliti aktivitas kelompok, budaya yang melambangkan perilaku manusia dalam kehidupan sehari-hari. Mengutip dari pendapat Afiyanti \& Rachmawati (2014, hal. 5) bahwa pendekatan kualitatif adalah sebagai penelitian yang pada umumnya memjelaskan, memberikan dan interpretasi tentang berbagai perilaku dan pengalaman manusia (individu) dari berbagai bentuk.

Sedangkan metode yang digunakan dalam penelitian ini yaitu metode studi kasus. Danial \& Wasriah (2019, hal. 64) mengungkapkan bahwa studi kasus ini tidak mengambil generalisasi, sebab kesimpulan yang diambil adalah kekhasan temuan kajian individu 'tertentu karakteristiknya' secara utuh menyeluruh yang menyangkut seluruh kehidupannya. Sedangkan menurut Bungin (2007, hal. 132) studi kasus adalah studi yang yang mendalam hanya pada suatu kelompok orang atau peristiwa. Berdasarkan pengertian tersebut, dapat dijelaskan bahwa metode studi kasus digunakan untuk meneliti secara seksama dan terperinci mengenai hal-hal yang diteliti. Penelitian ini akan 
menghasilkan sesuatu yang khas karena merupakan penelitian yang tertuju pada suatu unit.

Sumber data dari penelitian ini diperoleh dari data lapangan dan kepustakaan. Data lapangan berupa hasil observasi atau pengamatan langsung dan wawancara kepada para informan. Proses pengumpulan data dilakukan oleh peneliti melalui empat teknik pengumpulan data, yaitu: observasi, wawancara, studi dokumentasi dan studi literature. Analisis data dalam penelitian kualitatif terdiri atas tiga alur kegiatan yang dilakukan secara bersamaan yaitu: reduksi data, sajian data, dan penarikan kesimpulan/verifikasi (Creswell, 2010, hal. 244-245).

\section{HASIL DAN PEMBAHASAN}

\section{Profil Lembaga Pendidikan Pondok Pesantren Mancengan Darussalam}

Pondok Pesantren Mancengan Darussalam terletak di desa Langpanggang Modung Bangkalan Madura, Jawa Timur. Pesantren ini di dirikan pada tahun 1930 M oleh KH, Achmad. Asy'ari Bin Achmad. Rowi seorang ulama karismatik yang merupakan salah satu santri Syaikhona Moh Kholil Bangkalan (KH. Kholil Bin Abdul Latif). Secara geografis Pesantren Mancengan Darussalam terletak di pesisir selatan yang membatasi Surabaya dan Madura, dengan luas lahan 986 Meter. Setelah pendiri pesantren meninggal dunia, maka yang memimpin pesantren Mancengan Darussalam adalah cucu dari KH. Achmad. Asy'ari yaitu, KH. Ali Imron Salam yang merupakan putera tertua dari KH. Abu Abdussalam.

Pada awalnya pesantren ini di dirikan berdasarkan permohonan masyarakat luas, agar KH. Achmad Asy'ari sudi mendirikan pesantren. Akhirnya beliau mendirikan pesantren walau hanya sekedar gubuk dan aula tempat santri menimba ilmu agama. santri pada saat itu tergolong sedikit, dikarenakan kesadaran masyarakt dahulu belum terbuka dan disisi lain dalam satu kampung terdapat banyak pesantren yang masih mempunyai ikatan saudara. Metode yang digunakan dalam pesantren pun masih sederhana, hanya sebatas sorogan. Kajian yang sering diajarkan selain Al Quran adalah kitab klasik sepeti Safinatun Naja, Sullam Taufik, Bidaya.

Dulu santri memang tidak mengkaji banyak kitab, namun senlebih pada bagaimana santri menekuni ilmu yang telah di pelajari. Menurut KH. Ali Imron selaku pengasuh pesantren Mancengan Darussalam sekarang bahwa santri dulu memang dilatih keras tentang bagaimana cara menjalani hidup dengan ikhlas, patuh, tawaduk, sabar dan tawakal kepada Allah SWT.

Dari pernyataan KH. Ali Imron bahwa Pesantren Mancengan Darussalam mempunyai integritas dalam menciptakan manusia seutuhnya dengan pembentukan sikap terpuji santri. Sikap tersebut berkembang menjadi habituasi karakter santri dalam seharihari, senantiasa patuh, taat pada ajaran agama islam yang di sampaikan oleh Kyai Anjuran untuk selalu taat pada perintah Allah merupakan dasar utama ajaran dalam Islam, sebab ketaatan dan kepatuhan terhadap segala yang diperintahNya dapat bersinergi dengan elemen nilai dalam kehidupan yaitu membentuk keharmonisan, kedamaian, kejujuran, kesabaran, rasa kasih sayang, tolong menolong, rendah hati, mandiri. Hal-hal tersebut merupakan integritas ketakwaan manusia pada Allah SWT. Nah, dari metode sederhana itulah karakter santri dulu dibentuk. 
Dengan perkembangan zaman Pondok Pesantren Mancengan Darussalam semakin berkembang, dan berevolusi menjadi pesantren besar, di dalamnya terdapat berbagai macam pendidikan (formal dan nonformal). Pendidikan formal ini merupakan regulasi dan inovasi dari perkembangan pendidikan yaitu seperti SMP dan SMA, dari Ma'hadiyah terdapat Madarasah Diniyah dan Tsanawiyah. Sedangkan pendidikan nonformal merupakan warisan dari leluhur atau sesepuh pesantren yang masih dipertahankan dalam budaya pendidikan pesantren, khususnya di pesantren Mancengan Darussalam. Dari berbagai tuntutan dan perkembangan, kitab kuning yang dijadikan kajian rutin pesantren pun bertambah. Misalnya kitab Hadis, Tauhid, Tafsir, Akhlak, Sorrof, Nahwu serta masih banyak lainnya. Kajian-kajian tersebut sebenarnya tidak terlepas dari tuntutan perkembangan zaman, bahwa santri harus dapat bergerak dengan kaedeh-kaedeh yang di ajarkan oleh islam.

Namun, disisi lain masyarakat juga menuntut tentang solusi permasalahan yang ada di masyarakat mengenai hukum yang berhubungan dengan agama Islam. Tidak cukup disitu, santri untuk bisa terjun dan menghadapi masyarakat, membutuhkan kemampuan dalam berbicara, pidato, serta kedewasaan sikap, perilaku dan kesopanan dalam menghadapi masyarakat. Maka kyai dalam hal ini menyediakan berbagai macam pelatihan dalam berdakwa. Tidak hanya skill, namun bagaimana santri dapat memberikan cerminan pada masyarakat sebagai manusia yang berpendidikan dan ahli dalam agama.

Menurut KH. Ali Imron bahwa semua pendidikan baik SMP, SMA, maupun Diniyah dan Tsanawiyah dibuat di pesantren, tidak lain agar santri mempunyai wawasan dan akhlak yang lebih baik. Bukan hanya sekedar tentang ilmu agama, namun ilmu-ilmu yang lain bisa dikuasai. Tidak hanya itu, pembentukan pendidikan formal ini karena melihat Madura akan menjadi sebuah kota yang besar, apalagi Suramadu sudah menbentang dan mejadi pusat perhatian setiap kalangan. Jika santri hanya dibekali ilmu agama saja tidak cukup untuk menghadapi tantangan zaman. Mereka harus bisa berada dianatara mereka yang mengatur pemerintahan, turut berkontribusi. Maka dari itu, pengasuh menganjurkan agar santri giat untuk belajar dan sekolah agar mereka mempunyai ijazah yang dapat difungsikan nantinya.

Dari pernyataan tersebut bahwa santri tidak hanya dituntut menguasi ilmu agama, namun semua ilmu yang ada di pendidikan pesantren harus bersinergi dan memberi dampak pada cara berfikir santri. Tidak hanya sekedar menjadi orang baik. Namun kebaikan tersebut dapat memberikan perubahan dalam kehidupan sosial masyarakat dalam menghadapi perkembangan zaman. Santri dengan pendidikan dan pelatihan diharapkan dapat menjadi leader yang amanah, terampil, berakhlak, sopansantun, gemar menolong, mengayomi. Hal tersebut merupakan salah satu bentuk dakwah menyebarkan ajaran agama Islam.

\section{Pendidikan Kewarganegaraan (Citizenship Education) dan Nilai-nilai Pendidikan Pesantren.}

Sebelum kita mengenal lebih jauh seperti apa manfaat/pentingnya Pendidikan Kewarganegaraan (PKn) unntuk kita sebagai anak bangsa, kita harus memahami dulu apa pengertian dan sejarah singkat Pendidikan Kewarganegaraan.

Kata kewarganegaraan dalam bahasa Latin disebut civicus. Mengutip dari catatan sejarah bahwa civicus merupakan nama dari sebuah warga negara di Yunani dari negara kota, disebut negara kota karena pada saat itu yang dijadikan negara adalah sebuah kota, 
dan yang dijadikan sebagai warga negara adalah warga di kota tersebut. Selanjutnya, kata civicus diserap ke dalam bahasa Inggris menjadi kata civic yang artinya mengenai warga negara atau kewarganegaraan. Dari kata civic lahir kata civics yaitu ilmu kewarganegaraan. sedangkan civic education atau citizenship education, yaitu Pendidikan Kewarganegaraan (Wahab \& Sapriya, 2011).

Menurut Winataputra (2015) pelajaran civics atau kewarganegaraan telah diperkenalkan di Indonesia sejak zaman kolonial Belanda dengan nama burgerkunde pada era 1961 sampai 1968 yang menekankan pada dasar hukumnya yaitu konsepsi perbaikan sistem pendidikan nasional. Pada tahun 1900-an mata pelajaran civics berkembang menjadi new civics (pendidikan kewaganegaraan baru) yang menekankan pada konsepsi tentang community living (kehidupan masyarakat). Tetap ditahun yang sama 1900-an citizenship education diperkenalkan sebagai nomenklatur dari bentuk repsentasi dari bentuk charcter education (pendidikan watak/karakter) dan teaching personal ethics and virtus (pendidikan etika dan kebijaksanaan). Dan masih pada tahun 1900-an diperkenalkan istilah civic education yang merupakan bertukar pakaian dari citizenship education. Civic education semua merupakan proses pembelajaran (mata pelajaran), kegiatan siswa, administrasi dan pembinaan dalam upaya pengembangan perilaku warganegara yang baik.

Dari definisi tersebut dapat di ambil kesimpulan bahwa Pendidikan Kewarganegaraan dirumuskan secara luas yaitu mencakup proses penyiapan generasi muda atau warga negara menjadi lebih baik, demokratis, jujur, bertanggung jawab, mempunyai wawasan dan jiwa patriotisme, nasionalisme pada negara. Sedangkan secara khusus, peran pendidikan termasuk di dalamnya persekolahan, pengajaran dan belajar, dalam proses penyiapan warga negara tersebut menjadi warga negara yang ideal baik untuk dirinya, lingkungan dan juga masa depan bangsa.

Sementara itu, peserta didik/santri sebagai anak bangsa Indonesia diharapkan dapat menjadi generasi yang memahami pendidikan kewarganegaraan dan menjadi warga negara yang memiliki komitmen yang kuat dan konsisten untuk mempertahankan Negara Kesatuan Republik Indonesia (NKRI). Karena hakikat negara kesatuan Republik Indonesia adalah negara kebangsaan modern. Negara kebangsaan modern adalah negara yang pembentukannya didasarkan pada semangat kebangsaan atau nasionalisme yaitu tekad suatu masyarakat untuk membangun masa depan bersama di bawah satu negara yang sama, walaupun warga masyarakat tersebut berbeda-beda agama, ras, etnik, atau golongannya.

Jadi dari uraian tentang beberapa konsep dan definisi tentang Pendidikan Kewarganegaraan bertujuan untuk mendidik warga negara agar menjadi warga negara yang baik, yang dapat dilukiskan dengan warga negara yang patriotik, toleran, setia terhadap bangsa dan negara, beragama, demokratis, dan Pancasila sejati.

Melalui peranan Pendidikan Kewarganegaraan siswa diharapkan: a) Mampu Memahami dan menguasai secara nalar konsep dan norma Pancasila sebagai falsafah, dasar ideologi dan pandangan hidup Negara Kesatuan Republik Indonesia (NKRI); b) Memahami secara langsung apa itu konstitusi (UUD NKRI 1945) dan hukum yang berlaku dalam Negara RI; c) Menghayati dan meyakini tatanan dalam moral yang termuat dalam butir diatas; d) Mengamalkan dan membakukan hal-hal diatas sebagai sikap perilaku diri dan kehidupannya dengan penuh keyakinan dan nalar. 
Selaras dengan pendapat Wahab \& Sapriya (2011, hal. 35), tujuan Pendidikan Kewarganegaraan adalah untuk menghasilkan warga negara yang demokratis yaitu warga negara yang cerdas dan dapat memamfaatkan kecerdasanya untuk kemajuan masa depan bangsa Indonesia, dalam makro masa depan sendiri, lingkungan masnyarakat. Dan dapat berpartisipasi penuh nalar dan tanggung jawab dalam kehidupan politik dari warga negara yang taat kepada nilai-nilai dan prinsip-prinsip dasar demokrasi konstitusional Indonesia.

Jika dilihat dari kesimpulan akhir dari uraian dan definisi konsep Pendidikan Kewargenagraan tidak jauh berbeda dengan konsep nilai yang di miliki oleh Pendidikan Pondok Pesantren. Nilai-nilai pesantren orientasinya pada pembentukan karakter santri atau dapat juga disebut pesesrta didik. Karakter-karakter yang diterapkan dalam pesantren sebagai konsep nilai meliputi: kejujuran, keikhlasan, disiplin, taat, mandiri, dermawan, rendah hati, berjiwa sosial, gotong royong, toleransi, amanah, tidak sombong, sederhana, dan religius.

Menurut dari pendapat Attarmizi \& Kalam (1999, hal. 107-108) bahwa nilai-nilai Islam yang diajrkan pada para santri di pesantren, yaitu; 1) sidik, artinya benar, baik niat, perkataan maupun berbuatan/tindakan; 2) amanah, artinya dapat dipercaya, jujur terhadap segala sesuatunya, terbuka dan disiplin; 3) ta'awun, tolong menolong, gotong royong, saling mendukung dan saling menasehati.

Dari tiga konsep ini manusia atau santri dapat sampai pada dataran kesempurnaan sifatnya jika mereka atau ummat islam dapat menerapkan nilai-nilai tersebut dalam aktifitas sehari-harinya. Pesantren pun dalam membentuk peradaban karater santri berpatokan pada tiga tersebut. Disisi lain pesantren menerapkan apa yang telah dilakukan oleh Nabi Muhammad Saw sebagai Rasul panutan, sebagaimana yang telah tercantum dalam Al Quran:

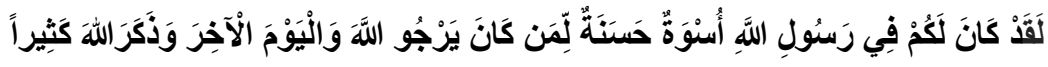

"Sungguh, telah ada pada (diri) Rasulullah itu suri teladan yang baik bagimu (yaitu) bagi orang yang mengharap (rahmat) Allah dan (kedatangan) hari Kiamat dan dia menyebut Allah"(Q.S.: Al Ahzab: 21).

Selain itu peradaban karakter Nabi Muhammad SAW, dari kecil hingga besar dijaga oleh Allah Swt dari sifat-sifat tercela. Diantara sifat yang lain misalnya: sabar, lemahlembut, pemaaf, warak/alim dan meninggalkan perkara yang syubhat, sopan, pemalu, menjaga pandangan, menjaga pendengaran, murah hati, suka menolong dan lainnya.

Pesantren merupakan lembaga penerapan sistem pendidikan Islam tradisional dan pribumi yang telah ada seiring dengan datangnya Islam. Keberadaan pesantren sebagai bagian dari pengajaran ajaran Islam menjadi denyut nadi perkembangan Islam itu sendiri. Sehingga, pesantren merupakan sistem pendidikan original yang telah membentuk keberagamaan dan perilaku masyarakat muslim dari generasi ke generasi (Ma'rifah \& Mustaqim, 2015, hal. 349).

Tim Direktorat Kelembagan Agama Islam Departemen Agama Republik Indonesia tahun 1986 tentang Standarisasi Pengajaran Agama di Pondok Pesantren, adalah: (1) menguasai ilmu agama dan mampu melahirkan insan-insan yang mutafaqquh fî al-dîn, (2) menghayati dan mengamalkan ajaran-ajaran islam dengan tekun, ikhlas semata-mata untuk berbakti kepada Allah SWT, (3) mampu menghidupkan Sunnah Rasulullah dan 
menyebarkan ajaran islam secara kâffah, (4) berakhlak luhur, berpikir kritis, berjiwa dinamis dan istiqamah, (5) berjiwa besar, kuat mental dan fisik, hidup sederhana, tahan uji, beribadah, tawadhu', kasih sayang terhadap sesama, mahabbah dan tawakkal kepada Allah SWT (Baidlawi, 2006, hal. 163). Hal yang seperti ini yang ingin dibangun oleh kyai pada peradaban karakter santri di Pesantren Mancengan Darussalam.

\section{Pesantren dalam Membentuk Keadaban Moral Santri}

Pendidikan Kewarganegaraan merupakan pendidikan yang membentuk watak kedewasaan manusia dalam menjalani kehidupan khsusnya sebagai warga negara. Pendidikan kewarganegaraan adalah perluasan dari ilmu pendidikan kewarganegaraan (civics) yang bertujuan untuk mengembangkan gaya berpikir kritis, cerdas dan dinamis setiap warga negara. Pendidikan kewarganegaraan merupakan wahana dalam menciptakan keadaban moral, taat pada peraturan, taat hukum. Bukan hanya itu, pendidikan kewarganegaraan menciptakan warga negara yang dapat mengenali jatidirinya sebagai warga negaranya.

Sedangkan Pendidikan Pesantren adalah pendidikan yang berkembang dan dikembangkan dalam lembaga pendidikan pesantren. Dengan artian pendidikan pesantren sebagai lembaga yang membentuk nilai-nilai moral, etika, keperibadian santri/bangsa dalam mengenal jatidirinya sebagai bangsa yang baik, dan lembaga pendidikan yang mempertahankan nilai-nilai budaya, nilai nasionalisme dan patriotisme, nilai kemandirian, nilai religius. Maka dari itu, sudah sepantasnya pendidikan pesantren menjadi akar pendidikan kewarganegaraan yang berkembang di negara Indonesia.

Dari hasil peneliti Baso (2012) dikemukakan mengenai pesantren sebagai akar pendidikan kewarganegaraan adalah didapatkan santri diajari tentang nilai demokratis, toleran kepada sesama, menghargai perbedaan (pluralisme), dan kosmopolit terhadap ilmu pengetahuan. Sikap-sikap tersebut ternyata merupakan fundamen ideologi bangsa kita. Berarti, memahami pesantren sebetulnya memahami bagaimana cara mencintai Bangsa dan Negara Indonesia. Dengan demikian, pendidikan pesantren adalah pendidikan Islam yang bermaksud menanamkan dan mencintai bangsanya sendiri.

Bukan kah teori Pendidikan Kewarganegaraan itu menurut Wahab \& Sapriya (2011) bertujuan untuk menciptakan warga negara yang baik. Warga negara yang baik adalah warga negara yang memahami dan melaksanakan hak-hak dan kewajiban, bertanggung jawab, menghargai hak-hak orang lain, taat hukum, dapat mempertahankan serta berperan aktif dalam menjaga kestabilitasan negara, menjaga keutuhan bangsa dengan menanamkan nilai-nilai Pancasila pada kehidupan berbangsa dan bernegara? Bukan kah tujuan kesadaran dalam ber-Pancasila menurut Wiratmoko \& Fahrudi (2016, hal. 1197) adalah untuk memahami setiap karakter bangsa di Indonesia demi menjaga keutuhan, persatuan dan kesatuan sehingga terbentuk lah sebuah persaudaraan, kesamaan, nasionalisme dan patriotisme di dalamnya. Maka hal tersebut yang ingin disampaikan keberadaban pesantren merupakan pendidikan yang punya peranan besar dalam membentuk karakter bangsa dan menjadi sewajarnya bahwa pendidikan didalam pesantren merupakan pendidikan yang memperkuat pendidikan kewarganegaraan.

Bagian kecil dari pendidikan yang ada di pesantren merupakan pendidikan kewarganegaraan yang menjadi muatan kurikulum dan bahan ajar dalam pelajaran yang telah diajarkan berdasarkan teori-teorinya dalam pendidikan formal (SMP dan SMA) yang berada di bawah naungan Pesantren Mancengan Darussalam, dengan pendidikan 
nilai pesantren yang mencerminkan nilai-nilai Pancasila dalam setiap pelaksanaan seharihari. Tentang bagaimana santri di didik untuk menjadi manusia kreatif, kritis, mandiri, mempunyai jiwa peduli, sosial yang tinggi, taat, dan juga rajin beribadah. Dalam meningkatkan kesadaran dan mengaplikasikan nilai-nilai Pancasila pada santri di pesantren Mancengan Darussalam memberi cirikhas yang beda dengan bangsa lain. Misalnya dalam berketuhanan, gotongroyong yang merupakan bentuk dari persatuan, musyawarah dan lain sebagainya.

Disisi lain pendidikan pesantren Mancengan Darussalam juga terdapat pendidkan nonformal (Madrasah Ibtidaiyah, Tsanawiyah, dan pengajian kitab-kitab klasik lainnya). Dalam pendidikan tersebut bemuatan prinsip tentang hal kehidupan bersosial, agama yang baik, berniaga, perkekonomian dan sebagainya. Salah satu kitab yang dikaji adalah Ta'limul Muta'allim, Hadits, Tafsir, Fiqqih dan lainnya.

Sopan santun adalah cirikhas yang tidak bisa dipisahkan dari ajaran yang menjadi prinsip hidup kyai pesantren. Nah itu yang hingga kini masih diwariskan pada santri di pondok pesantren Mancengan Darussalam. Kebiasaan ulama dengan kemulian akhlaknya sering kali dijadikan teladan oleh para santri dan masyarakat. Kebiasaan inilah yang dibawa santri dan diterapkan walaupun sudah berhenti menjadi santri, peneliti menyebutnya sebagai pendidikan informal pesantren. Salah satu idealisme santri saat berhenti menjadi santri adalah apa yang dilakukandan diperintah oleh guru/kyai di pesantren masih dipakai diluar pesantren. Misalnya, hidup rukun bertetangga, saling menghormati, menjaga silaturahmi, tanpa memandang perbedaan yang semua merupakan identitas budaya bangsa Indonesia yang sampai saat ini masih dipertahankan dan ajarkan pada santri oleh pesantren.

Winataputra \& Budimansyah (2012, hal. 233) mengatakan bahwa secara teoritik, konsep civil culture atau budaya Pancasila untuk Indonesia, terkait erat pada perkembangan democratic civil society atau masyarakat madani Pancasila yang mempersyaratkan warganya untuk melakukan proses individualisasi, dalam pengertian bahwa setiap orang harus melihat dirinya sebagai individu dan orang lain sebagai individu yang merdeka, yang sama tidak lagi meributkan atau memakai atribut-atribut khusus. Misalnya, agama, etnis, dan kelas dalam masyarakat. Konsep dari kesadaran berPancasila bukan hanya sepintas pemahaman dan pengetahuan saja, namun aktualisasi dari kesadaran tersebut dibentuk dalam sikap dan karakter kehidupan sehari-hari sebagai warga negara yang baik dan Pancasilais. Konsep kesadaran ber-Pancasila harus di aktualisasikan dengan rasa cita pada tanah air, negara, bangsa, masyarakat, peduli pada lingkungan, peduli pada permasalahan masyarakat, peduli pada ketahanan dan keutuhan negara, peduli pada semua yang berkaitan dengan kestabilan bangsa dan negara (Mardawani \& Kurniati, 2007, hal. 42). Maka tidak salah jika cinta tanah air merupakan puncak karakter terbaik bangsa Indonesia.

Sedangkan nilai seperti itu sudah pesantren tunjukkan sejak dulu. Menurut catatan sejarah pesantren dan santri serta ulama dalam merebut kemerdekaan dari antek-antek Belanda dan Jepang jasanya tidak dapat di bohongi. Salah satu yang sangat fenomenal adalah seruan KH. Hasyim Asyari. Beliau di kenal sangat berpengaruh dalam menciptakan semangat membara Indonesia khususnya ummat Islam, untuk merebut kemerdekaan bangsa Indonesia dengan seruan Jihad fisabilillah atau dikenal dengan resolusi Jihad. Tepatnya pada Senin Pahing, 17 September 1945/9 Syawal 1364, sebagai bentuk Hubbul Waton Minal Iman (cinta tanah air sebagian dari Iman). Resolusi Jihad 
yang di keluarkan oleh beliau merupakan bentuk penjelasan atas pertanyaan Presiden Soekarno yang memohon fatwa hukum mempertahankan kemerdekaan bagi ummat Islam. Hingga penjajah menyatakan menyerah terhadap kekuatan bangsa Indonesia.

Dalam perumusan Dasar Negara,Maarif (2017, hal. 136-137) mengatakan bahwa wakil-wakil dari golongan Islam yang ikut merumuskan Pancasila antara lain adalah KH. A. Sanusi (PUI), Ki Bagus Handikusumo, KH. Mas Mansur, Abdul Kahar Muzakkir (Muhammadiyah), KH. A Wahid Hasyim, KH. Masykur (NU), Sukiman Wiryosanjoyo (PSII), Agus Salim (Penyadar sebelum perang dunia ke (II), dan KH Abdul Halim (PUI). Jika dilihat dari tim perumus tersebut tidak salah jika masyarakat/bangsa mengakatakan bahwa Pancasila di ilhami oleh nilai-nilai islam. Dan dari uraian tersebut mengenai para pelopor ulama bukan hal keniscayaan mereka tidak mempunyai pengikut atau santri dan pesantren. Tentu mereka mempunyai pesantren yang karakter kebangsaannya diwariskan pada para santri untuk menjaga NKRI (Negara Kesatuan Republik Indonesia). Nah maka dari itu mengenai prihal bahwa salah satu tujuan Pendidikan Kewarganegaraan itu adalah mempertahankan kestabilan negara Indonesia yang mulai dulu hingga saat ini pesantren lakukan.

\section{Dampak Terintegrasi Pendidikan Pesantren pada Pendidkan Kewarganegaraan}

Penanaman nilai-nilai Pancasila pada kehidupan, tidak terlepas dari peran lembaga, bangsa, masyarakat dan lingkungan untuk menjadikan warga negara yang baik, yaitu warga negara yang mempunyai keperibadian luhur, karakter ideal yang membedakan satu bangsa dengan bangsa lainnya.

Wahab dan Sapriya (2011, hal. 40) berpendapat bahwa sebagai bangsa dan negara harus dapat mengakui betapa pentingnya pembentukan karakter sebagai bangsa (nition and character building) dalam rangka mempertahankan dan memelihara eksistensinya sebagai suatu bangsa. Kesadaran suatu bangsa dalam mempertahankan nilai-nilai yang menjadi sumber identitas bangsa memang sangat diperlukan. Identitas itu bersumber dari budaya (budi dan daya) asli Indonesia yang bermuatan dari hasil berpikir (logika), kemauan (etika), serta persamaan (estetika) dalam rangka perkembangan dan pengembangan peribadi manusia dalam hidup bersosial, sehingga hal tersebut menciptakan nilai dan dapat dijadikan argumen dalam mempertahankan identitas sebagai bangsa Indonesia (Panjaitan \& Sundawa, 2016, hal. 65). Maka dari itu meningkatkan kesadaran dan mengaplikasikan nilai-nilai Pancasila memberi cirikhas perbedaan dengan bangsa yang lain.

Menurut hasil temuan di lapangan bentuk-bentuk perilaku yang mencerminkan nilai-nilai Pancasila pada kehidupan santri di pesantren Mancengan Darussalam, di antaranya seperti mengikuti program-program di pesantren. Misalnya, shalat wajib 5 waktu, salat sunnah, membaca Al quran, membaca Nadham, mengikuti kegiatan Istighatsah, Dzikir bersama, ikut menjaga ketertiban dengan mentaati peraturan pesantren, jujur, adil, mandiri, akur, toleransi, saling membantu, gotong royong, giat belajar, menjaga kebersihan, kesopanan, ketaatan, cinta tanah air dengan mengikuti upacara bendera setiap hari senin dan hari-hari nasional, serta melestarikan budaya.

Baso (2012, hal. 163-165) berpendapat bahwa pesantren masih kental dalam merawat budaya-budaya yang dipertahankan ulama terdahulu yaitu persatuan dan kesatuan. Terciptanya kemerdekaan dikarenakan persatuan dan kesatuan yang kuat. Budaya seperti itu terdapat di Pesantren, yang merupakan aset paling berharga, karena 
dalam menjaga persaudaraan, menghormati, tolong menolong, persatuan, dan gotong royong sampai sekarang masih terawat, sedangkan di luar pesantren mulai terkikis oleh perkembangan zaman dan kemajuan global.

Perilaku yang mencerminkan nilai-nilai Pancasila di pesantren merupakan miniatur budaya yang ada di Indonesia. Sebagaimana yang dikatakan Baso (2012) bahwa pesantren adalah pendidikan islam pertama kali di Indonesia, dan didalamnya terdapat pembiasaan-pembiasaan (habituasi) dalam merawat budaya yang diwarisi oleh ulama terdahulu. Pembiasaan tersebut adalah menghargai. Ciri has pesantren dalam mengahargai, hingga sampai saat ini masih terjaga utuh. Budaya menghargai bukan hanya sebatas dilingkup internal pemahaman seakidah saja, namun lebih luas jangkauannya. Hal ini merupakan hasil penanaman ulama terdahulu dalam berdakwah, menanamkan nilainilai ke-Islam-an pada manusia. Perbedaan berpikir merupakan sebuah ekpresi dari kemampuan dan pemahaman manusia. Jadi, menghargai sebuah perbedaan tersebut merupakan sikap bijak yang dilakukan ulama dalam segala hal. Hingga budaya tersebut sampai saat ini masih dilakukan oleh santri di pesantren. Nah, hal seperti itu lah yang menjadi cerminan langka dari nilai-nilai Pancasila di kehidupan santri.

Pola dalam mengamalan nilai Pancasila santri, diimbangi dengan pengetahuan yang luas untuk memahami arti sila pertama. Menghargai agama orang lain, dalam pendidikan pesantren sudah diterapkan mulai dulu oleh para ulama. Bukti yang nyata adalah terciptanya sebuah persatuan yang dikemas dengan persepakatan Pancasila sebagai Dasar Negara. Rachmah (2013, hal. 10) bertkata bahwa Pancasila merupakan sublimasi nilainilai budaya yang menyatukan masyarakat Indonesia beragam suku, ras, bahasa, agama, pulau, menjadi bangsa yang satu, damai dan tenteram tidak ada permusuhan antara satu dan yang lain. Nilai-nilai yang terkandung dalam Pancasila tersebut (Kaelan, 2013) sebagai berikut:

Sila ketuhanan yang Maha Esa, yang mengandung arti pengakuan adanya kuasa prima (sebab pertama) yaitu Tuhan yang Maha Esa, menjamin penduduk untuk memeluk agama masing-masing dan beribadah menurut agamanya, tidak memaksa warga negara untuk beragama, menjamin berkembang dan tumbuh suburnya kehidupan beragama, bertoleransi dalam beragama, dalam hal ini toleransi ditekankan dalam beribadah menurut agamanya masing-masing (Tukiran \& Udhie, 2014, hal. 8).

Sila kedua manusia memiliki hakikat pribadi yang mono-pluralis terdiri atas susunan kodrat jiwa raga, serta berkedudukan sebagai makhluk pribadi yang berdiri sendiri dan makhluk TuhanYang Maha Esa. Nilai luhur kemanusiaan akan menumbuhkan sikap harmonis, menghormati hak asasi manusia, anti penjajahan, mengutamakan kebenaran dan keadilan, mencintai sesama manusia, tenggang rasa, dan sebagainya (Surip, Syarbaini, \& Rahman, 2015, hal. 18-20).

Sila ketiga berupa pengakuan terhadap hakikat satu tanah air, satu bangsa, dan satu negara Indonesia, tidak dapat dibagi sehingga seluruhnya merupakan suatu keseluruhan dan keutuhan. Nilai luhur persatuan terkandung di dalamnya cinta tanah air, tidak membeda-bedakan sesama warga negara Indonesia, cinta perdamaian dan persatuan, tidak mengagung-agungkan bangsa sendiri, suku, dan daerah tertentu (Tukiran \& Udhie, 2014, hal. 12).

Sila keempat sebuah kalimat yang secara bahasa membahasakan bahwa Pancasila pada sila ke-4 adalah penjelasan negara demokrasi. Dengan analisis ini diharapkan 
diperoleh makna yang akurat dan mempunyai nilai filosofis yang diimplementasikan secara langsung dalam kehidupan bermasyarakat. Tidak hanya itu, sila ini menjadi banyak acuan dari setiap langkah pemerintah dalam menjalankan setiap tindakannya. Yaitu menjunjung dan mengakui adanya rakyat yang meliputi keseluruhan jumlah semua orang warga dalam lingkungan daerah atau negara tertentu yang segala sesuatunya berasal dari rakyat dilaksanakan oleh rakyat dan diperuntukkan untuk rakyat.

Sila kelima mengakui hakikat adil berupa pemenuhan segala sesuatu yang berhubungan dengan hak dalam hubungan hidup kemanusiaan. Nilai luhur yang terkandung di dalamnya adalah mencintai keadilan sosial, cinta kekeluargaan, suka bekerja keras, menghormati kedaulatan bangsa lain, dan menganggap bangsa lain sederajat (Kaelan, 2013, hal. 413). Sila pertama menjiwai dan mendasari sila kedua, ketiga, keempat, dan kelima; sila kedua dijiwai dan didasari sila pertama, menjiwai dan mendasari sila ketiga, keempat, dan kelima; sila ketiga dijiwai dan didasari sila pertama dan sila kedua, menjiwai dan mendasari sila keempat dan kelima; sila keempat dijiwai dan didasari sila pertama, kedua, dan ketiga, menjiwai dan mendasari sila kelima; dan sila kelima dijiwai dan didasari sila pertama, kedua, ketiga, dan keempat. Itulah yang dinamakan Pancasila hierarkis piramidal.

Pesantren dalam penerapkan nilai-nilai yang mencerminkan Pancasila pada kehidupan santri terdapat kendala, sehingga bagian kecil para santri terkadang tidak dapat mengimbangi aktivitas dan hal-hal yang mendukung perkembangan nilai-nilai Pancasila pada santri. Faktor ini diakibatkan karena kurang pemahaman dan bimbingan intensif pada santri, dikarenakan kurangnya tenaga yang ada di pesantren Mancengan Darussalam. Di sisi lain adanya pengaruh-pengaruh dari luar, yang mengakibatkan perilaku santri kurang mencerminan nilai-nilai Pancasila.

Upaya pesantren dalam mengentaskan permasalahan ini, dilakukan dengan hal-hal yang progresif. Misalnya lebih memusatkan pada individu dengan menggunakan pendekatan persuasif, memberi stimulus, arahan, dan juga tindakan-tindakan yang lebih membangun kesadaran santri, sehingga santri dapat kembali menjadi sosok yang mencerminkan sebagai orang yang berpengetahuan luas tentang ilmu agama Islam dan ilmu yang lainnya.

Nah dari fakta yang ada tidak sedikit jebolan pesantren yang saat ini berperan dalam kepemeritahan, dan menjadi pengembang dalam menyiapkan kemajuan negara Indonesia. Maksud dari hal ini, masa keemasan pesantren dalam mencetak generasi agar semakin meningkat dan berkembang. Pendidikan Kewarganegaraan di Indonesia harus berdasarkan Pancasila, sedangkan Pancasila dalam catatan sejarah berakar dari nilai-nilai yang berkembang dimasyarakat Indonesia, budaya dan juga agama.

\section{SIMPULAN}

Dalam kesimpulan ini yang paling dominan mempengaruhi kultur kebudayaan (civil culture) atau kehidupan sosial (civil society) santri dalam menciptakan kehidupan madani adalah nilai pesantren dari konsep pengembangan ajaran Islam dan nilai luhur para leluhur yang sejak dulu hingga sekarang masih dipertahankan dan diajarkan ulama/ kyai jauh sebelum Indonesia terbentuk, nilai-nilai itu sudah ada dalam kehidupan pesantren yaitu nilai yang mencerminkan Pancasila. 
Karakter pendidikan pesantren lebih bersifat sederhana dan kekeluargaan. Sedangkan upaya pesantren dalam melakukan pembentukan keadaban moral melalui, 1) pendidikan formal, misalnya SMP, dan SMA yang didalamnya memuat pendidikan Pancasila dan Kewarganegaraan; 2) melalui pendidikan nonformal yang didalamnya berisikan pelajaran-pelajaran tentang norma agama (hadist, tafsir, al qu'an, fiqqih, akhlak dll.); 3) pendidikan Informal, pendidikan yang tidak terikat dengan sesuatu apapun, tempat kurikulum, dan waktu, yaitu keteladana ulama karismatik yang dicontoh oleh santrinya.

Bentuk sikap/ perilaku santri dari integrasi pendidikan pesantren, yaitu nilai-nilai yang mencerminkan Pancasila. Nilai ini lah yang selalu diterapkan dalam kehidupan santri di pesantren yang pertama memang merupakan warisan dari leluhur, kedua memang ajaran yang dikembangkan dalam lembaga pendidikan Pondok Pesantren Mancengan Darussalam. Misalnya dalam keadaban ber-ketuhanan, kemanusiaan, persatuan, dan keadilan, jujur, disiplin, mandiri, religious, dan taat aturan.

\section{UCAPAN TERIMA KASIH}

Untaian kata terima kasih saya haturkan atas selesainya penelitian ini kepada segenap majlis keluar Pondok Pesantren Mancengan Darussalam yang telah sudi menerima saya untuk melakukan penelitian di pesantren. Terima kasih saya haturkan kepada simpatisan santri dan juga dewan guru serta para pengurus Pesantren Mancengan Darussalam, karena telah meluangkan waktunya untuk memberikan informasi mendalam mengenai aktivitas-aktivitas pesantren. Terima kasih saya haturkan kepada kedua orang tua atas segalanya doa dan kasih sayangnya, serta kepada guru-guru saya atas segala nasehat dan bimbingannya.

\section{DAFTAR PUSTAKA}

Afiyanti, Y., \& Rachmawati, I. N. (2014). Metodologi Penelitian Mualitatif dalam Riset Keperawatan. Jakarta: PT Raja Grafindo Perseda.

Attarmizi, Y. A., \& Kalam, M. Y. (1999). KH Mohd. Ilyas Ruhiat, Ajengan Santun dari Cipasung: Membedah Sejarah Hidup dan Wacana Pemikiran Islam Keumatan. Bandung: PT. Remaja Rosdakarya.

Baidlawi, H. M. (2006). Modernisasi Pendidikan Islam (Telaah Atas Pembaharuan Pendidikan di Pesantren). Tadris, 1(2). https://doi.org/10.19105/jpi.v1i2.198

Baso, A. (2012). Akar Pendidikan Kewarganegaraan di Pesantren. Jurnal Pendidikan Islam UIN Sunan Gunung Djati, 27(2), 161-186. https://doi.org/10.15575/jpi.v27i2.503

Budiman, A., \& Ismatullah, F. (2015). Penerapan Pendidikan Akhlak di Sekolah Menengah Pertama Islam Terpadu Darut Taqwa Jenangan Ponorogo Tahun Ajaran 2014-2015. At-Ta'dib, 10(1), 155-175. https://doi.org/10.21111/ATTADIB.V10I1.330

Budimansyah, D. (2010). Penguatan Pendidikan Kewarganegaraan Untuk Membangun Karakter Bangsa. Bandung: Widya Aksara Press.

\section{JURNAL KEWARGANEGARAAN}


Bungin, B. (2007). Penelitian Kualitatif: Komunikasi, Ekonomi, Kebijakan Publik, dan Ilmu Sosial Lainnya. Jakarta: Prenada Media Group.

Creswell, J. W. (2010). Research Design: Pendekatan Kualitatif, Kuantitatif, dan Mixed. Yogyakarta: Pustaka Pelajar.

Danial, E., \& Wasriah, N. (2019). Metode Penulisan Karya Ilmiah. Bandung: Laboratorium Pendidikan Kewarganegaraan.

Kaelan, H. (2013). Negara Kebangsaan Pancasila Kultural Historis, Filosofis Yuridis dan Aktualisasinya. Yogyakarta: Paradigma.

Ma'rifah, S., \& Mustaqim, M. (2015). Pesantren Sebagai Habitus Peradaban Islam Indonesia. Jurnal Penelitian, 9(2), 347-366. https://doi.org/10.21043/jupe.v9i2.1325

Maarif, A. S. (2017). Islam dan Pancasila sebagai Dasar Negara: Studi Tentang Perdebatan dalam Konstituante. Kerja sama Penerbit Mizan dan Maarif Insitute for Culture and Humanity.

Magnis-Suseno, F. (1987). Etika Politik: Prinsip Moral Dasar Kenegaraan Modern. Jakarta: PT Gramedia Pusaka Utama.

Mardawani, \& Kurniati, A. (2007). Model Pembinaan Rasa Kebangsaan Melalui Citizenship Education Pada Masyarakat Entikong Wilayah Perbatasan IndonesiaMalaysia. Jurnal Ilmiah Pendidikan Pancasila dan Kewarganegaraan, 1(2), 4147. https://doi.org/10.17977/um019v2i12017p041

Panjaitan, L. M., \& Sundawa, D. (2016). Pelestarian Nilai-Nilai Civic Culture dalam Memperkuat Identitas Budaya Masyarakat: Makna Simbolik Ulos dalam Pelaksanaan Perkawinan Masyarakat Batak Toba di Sitorang. Journal of Urban Society's Arts, 3(2), 64-72. https://doi.org/10.24821/jousa.v3i2.1481

Rachmah, H. (2013). Nilai-nilai dalam Pendidikan Karakter Bangsa yang Berdasarkan Pancasila dan UUD 1945. E-Journal WIDYA Non-Eksakta, 1(1), 7-14.

Surip, N., Syarbaini, S., \& Rahman, A. (2015). Pancasila dalam Makna dan Aktualisasi. Yogyakarta: CV. Andi Offset.

Susilo, L. (2015). Peningkatan Hasil Belajar Pendidikan Kewarganegaraan dengan Menggunakan Metode Bermain Peran Kelas IV Sekolah Dasar Kabupaten tanah Tidung. Jurnal Pendidikan Dasar, 6(1), 24-35. https://doi.org/10.21009/jpd.061.03

Tukiran, T., \& Udhie, H. (2014). Pemimpin Berkarakter Pancasila. Bandung: Alfabeta.

Wahab, A. A., \& Sapriya. (2011). Teori \& Landasan Pendidikan Kewarganegaraan. Bandung: Alfabeta.

Winataputra, U. S. (2015). Pendidikan Kewarganegaraan: Refleksi Historisepistemologis dan Rekonstruksi untuk Masa Depan. Tangerang Selatan: Universitas Terbuka.

Winataputra, U. S., \& Budimansyah, D. (2012). Pendidikan Kewarganegaraan dalam Perspektif Internasional: Konteks, Teori, dan Profil Pembelajaran. Bandung: Widya Aksara Press. 
